\title{
Energy performance evaluation of energy performance calculation method in buildings (Bep-Tr1)
}

\author{
D. Saylam Canım* and Ö. Aydın \\ Karadeniz Technical University, Faculty of Architecture, Department of Architecture, Trabzon, Turkey
}

\begin{abstract}
The provision, determined by the "Energy Performance of Buildings Regulations", which requires that the energy performance classification of the new and already existing buildings need to meet a minimum " $C$ " energy class, has increased awareness in the construction sector regarding the heat insulation applications. However, in this process, we are confronted with the thermal insulation applications that are carried out in standard thickness without taking into consideration the climatic region where the buildings are located. The purpose of this study is to compare the impact of the thermal insulation applications which are carried out in standard thickness without taking the climatic region into consideration with the applications carried out by using optimum thermal insulation on the energy loads of the buildings and building energy classes obtained in the consequence of calculations in the Bep-Tr1 software. For this purpose, the energy performances of the sample residential building in the pilot cities in five climatic regions (Antalya, Trabzon, Ankara, Diyarbakır, Erzurum) are determined by using both the standard and the optimum thermal insulation thickness values and in the Bep-Tr1 software, the impact of the head insulation thickness on the building's energy class has been investigated. The conducted study has shown that by using optimum thermal insulation thickness values, an average of $9 \%$ efficiency may be obtained in all regions in the building heating and cooling energy loads. However, the obtained efficiency was not sufficient to change the buildings' energy class in every region.
\end{abstract}

\section{Keywords}

Bep-Tr1; Energy efficiency; Optimum thermal insulation; Building energy class; External wall

Received: 05 February 2019; Accepted: 24 March 2019

ISSN: 2630-5771 (online) () 2019 Golden Light Publishing All rights reserved.

\section{Introduction}

Nowadays, the energy need gradually increases due to the technological improvements after the industrial revolution and changes in lifestyles. In the last two hundred year-process fossil fuels have found a widespread area of usage due to the changes that took place in production technologies and that they are cheap, and as a result of this, they have become superior against renewable technologies. However, the decline in the reserves of the fossil fuel energy sources and the fact that they would deplete someday have lead the politicians to make searches regarding new energy sources and an intense interest regarding new and renewable energy sources has emerged all around the world.

Around the world, approximately $40 \%$ of the total energy consumption takes place in the buildings and as a result of this consumption, 24\% of the total $\mathrm{CO}_{2}$ released into the atmosphere has originated from energy consumption in buildings

* Corresponding author

Email: dsaylam@hotmail.com 
[1]. The climatic region where the building is located and the optimum thermal insulation thickness determined for that particular climatic region are a significant influential factor in determining the energy performance of the building. Some of the studies made on the determination of the optimum thermal insulation thickness values and its impact on the energy performance of the building are as follows: Çomaklı and Yüksel [2] have determined the optimum thermal insulation thicknesses for Erzurum, Kars and Erzincan which are among the coldest cities of Turkey. The optimum thermal insulation thickness has been calculated as $10.5 \mathrm{~cm}$ for Erzurum, $10.7 \mathrm{~cm}$ for Kars, and $8.5 \mathrm{~cm}$ for Erzincan. Bolattürk [3] has indicated the optimum thermal insulation thicknesses between 2 and 17 centimeters for 16 provinces from 4 different degree-day regions of Turkey. Kaynaklı and Yamankaradeniz [4] have determined the heating season of a sample region and calculated the optimum thermal insulation thickness by taking the energy cost into consideration. In their study, they have studied the necessary insulation thickness of the region based on the type of the walls, heat transfer coefficient of the insulation material and the degree day count of the region, and they have indicated that the increase of the total heat transfer coefficient of the wall decreased the optimum thermal insulation thickness while the increase of the day and the $\mathrm{k}$ value of the insulation materials increased the optimum thermal insulation thickness. Additionally they have indicated that the optimum thermal insulation thickness in turkey has varied in a wide range as 2.8 and 9.6 centimeters and thus in the calculations of energy efficiency and heating and cooling of the buildings, individually climatic conditions need to be determined on the basis of the sub provinces as well as the provinces. Özel and P1htılı [5] have determined the optimum thickness of the insulation applied to the external walls by taking them into consideration alongside with heating and cooling degree day values. The calculations have been made for the provinces of Adana, Elazığg, Erzurum, İstanbul and İzmir. In this case, the optimum thermal insulation thickness, energy savings and payback period have been calculated according to the increased insulation thicknesses by applying extrude polystyrene insulation to the external walls. With the conducted study, it has been concluded that the optimum insulation thickness has varied between 4 and 8.4 centimeters according to the analyzed provinces. Gürel and Cingiz [6] have calculated the optimum thermal insulation thickness value between 0.05 and 0.13 meters in the external wall model where natural gas is used as the fuel and bricks are used as the building material. Kürekçi et.al. [7] have determined the necessary optimum thermal insulation thickness values for 81 provinces according to the used thermal insulation material and fuel type. For the purpose of using energy more efficiently in buildings, in 2008, the Energy Performance of Buildings Directive in Turkey was issued and as the European Directive stipulated, the necessity to obtain Energy Performance Certificate was introduced for every building. The Building Energy Performance Software (Bep-Tr1), which is the national calculation method software to be used in the preparation of the Energy Performance Certificate, has been completed in 2011. The provision, determined by the taking into effect of the law, which requires that the energy performance classification of the new and already existing buildings need to meet a minimum " $\mathrm{C}$ " energy class, has increased awareness in the construction sector regarding thermal insulation applications. However, in this process, we are confronted with the thermal insulation applications that are carried out insensibly in standard thickness without taking into consideration the climatic region where the buildings are located.

\section{Methodology of study}

The energy performance calculation method in buildings (Bep-Tr) has been developed to evaluate the impact of all parameters affecting the energy consumption of buildings on the energy efficiency of the buildings and to determine the energy performance and greenhouse gas emission classifications. The calculation method has been used to evaluate the energy performance of the 
building typologies such as residential buildings, offices, educational buildings, health buildings, hotels, shopping and commercial centers which already exist or will be built. The registered users of the Bep-Tr system are the Ministry, energy efficiency consultancy, independent consultant engineers and energy performance experts [8].

For the energy performance evaluation of buildings, the provincial or sub provincial climatic data where the building is located are used. According to meteorological analyses, Turkey is divided into five climatic regions, namely the mildhumid, mild-dry, cold, hot-humid and hot-dry climatic regions. The criteria to separate into zones vary based on the functions of buildings. However, in all functions, as the areas between stories and the existence of obstacles might change, every story is taken as a separate zone even if the systems, internal gains and comfort temperature values are the same in between the stories.

In the calculation method, the angle that the building makes with the south is taken into consideration while determining the orientation of the building. The solar energy gains are studied in two levels namely the opaque and transparent components. The developed method takes into consideration the external obstacles, the shadowing impact of the protrusions of the building, and the amount of thermal radiation which is lost in the air. For a building to obtain construction permit, its Energy Performance Certificate, indicating that its energy performance is at least in " $\mathrm{C}$ " classification needs to be created by the Bep-Tr1 software and to be approved by the related municipality. The provision, which requires that the energy performance classification of the new and already existing buildings need to meet a minimum " $\mathrm{C}$ " energy class, has increased awareness in the construction sector regarding thermal insulation applications. However, in this process, we are confronted with the thermal insulation applications that are carried out insensibly in standard thickness without taking into consideration the climatic region where the buildings are located.

The purpose of the study is to compare the impact of the thermal insulation applications which are carried out in standard thickness without taking the climatic region into consideration with the applications carried out by using optimum thermal insulation on the energy loads of the buildings and building energy classes obtained in the consequence of calculations in the Bep-Tr1 software. For this purpose, the energy performances of the sample residential building in the pilot cities in five climatic regions (Antalya, Trabzon, Ankara, Diyarbakır, Erzurum) are determined by using both the standard and the optimum thermal insulation thickness values and in the Bep-Tr1 software, the impact of the thermal insulation thickness on the building's energy class has been investigated.

While determining the angle that the building makes with the south during the entry of the data related to the orientation of the buildings in Bep$\operatorname{Tr} 1$, the optimum direction angles determined for each climatic region are indicated in Table-1.

While determining the thermal insulation materials to be used in the conducted study, the thermal insulation materials of mineral wool (MW), expanded polystyrene (EPS), extrude polystyrene (XPS) and polyurethane (PU)are studied, which are more frequently used in the insulation of the buildings' external shells, and the XPS is preferred as it is most frequently used in the external thermal insulation applications. In the conducted study, the heating and cooling energy load analyses of the sample building in the five climatic regions have been carried out in the scope of two studies named "Scenario I" and "Scenario II" alongside with the changes made in the thickness of the XPS thermal insulation material used in the external shell of the building.

\section{- Scenario I}

While calculating the heating and cooling energy loads of the sample building, the thickness value of the XPS thermal insulation material used in the outer shell of the sample building is accepted as 5 $\mathrm{cm}$ in all five climatic regions, and the energy class is determined by making the calculation of the heating and cooling energy loads of the sample building in five pilot cities in the Bep-Tr1 software. 
Table 1. Optimum direction angles according to climatic regions

\begin{tabular}{|c|c|c|c|c|c|}
\hline Climatic Region & $1^{\text {st }}$ Region & $2^{\text {nd }}$ Region & $3^{\text {rd }}$ Region & $4^{\text {th }}$ Region & $5^{\text {th }}$ Region \\
\hline Pilot city & Antalya & Trabzon & Ankara & Diyarbakır & Erzurum \\
\hline $\begin{array}{l}\text { Optimum Direction } \\
\text { Angle that It Makes With } \\
\text { South }\end{array}$ & $3^{0}$ & $10^{0}$ & $27^{0}$ & $18^{0}$ & $22^{0}$ \\
\hline
\end{tabular}

In the consequence of the calculations made through the limit values in the TS 825 Standards for Thermal Insulation Rules in Buildings located in the present regulations of the Turkish Standards Institute, the average thermal insulation thickness value used for the 4 degree day region located in the standard is between 2 and $7 \mathrm{~cm}$ [9]. While determining the heat insulation thickness value in Scenario I, the TS 825 Standard is taken into consideration and the average thermal insulation thickness value used in Turkey has been determined as $5 \mathrm{~cm}$.

\section{- Scenario II}

While calculating the heating and cooling energy loads of the sample building in five climatic regions, all building components are regarded as the same as those in "Scenario I" and only the thickness value of the thermal insulation used in the outer shell of the building is changed. In the event that XPS is used as the heat insulation material, natural gas is used as the fuel, and bricks are used as the external wall component, the optimum thickness values, which need to be applied, are taken into consideration (Table 2) [10], the energy class and the heating and cooling energy loads of the sample building in five pilot cities are determined through the calculations made in the Bep-Tr1 software.

In order to obtain maximum efficiency from the conducted analysis, a plain and non-complex building is selected as the "sample building". It is assumed that the sample building has a basement and two stories, there are two apartments at each floor and the basement level is used as car parking area (Fig. 1).

General information regarding the sample building which is entered a during the building energy performance calculation by the Bep-Tr1 software are provided in Table 3.

The sample building consists of a total of 11 zones including 6 apartment zones, 3 core zones, 1 roof zone and 1 car parking area zone. As independent single zone calculation series, separate calculations are made for each zone and the obtained results are indicated in Table 4.

In the conducted study, in all five climatic regions, double glass unit with $9 \mathrm{~mm}$ gap filled with argon gas in the dimensions of $4 \mathrm{~mm} \times 9 \mathrm{~mm} \times 4$ $\mathrm{mm}$ is preferred as the buildings' transparent element of external wall. The characteristics regarding the element are provided in Table 5.

Table 2. Optimum thermal insulation thicknesses that need to be used in the selected pilot cities

\begin{tabular}{cccccc}
\hline \multicolumn{5}{c}{ According to Natural Gas dopt } \\
\hline Cities & Mineral Wool & Glass Wool & EPS & XPS & PU \\
\hline Antalya & $5 \mathrm{~cm}$ & $7 \mathrm{~cm}$ & $4 \mathrm{~cm}$ & $5 \mathrm{~cm}$ & $2 \mathrm{~cm}$ \\
Trabzon & $7 \mathrm{~cm}$ & $9 \mathrm{~cm}$ & $5 \mathrm{~cm}$ & $7 \mathrm{~cm}$ & $2 \mathrm{~cm}$ \\
Ankara & $9 \mathrm{~cm}$ & $12 \mathrm{~cm}$ & $7 \mathrm{~cm}$ & $9 \mathrm{~cm}$ & $3 \mathrm{~cm}$ \\
Diyarbakır & $8 \mathrm{~cm}$ & $10 \mathrm{~cm}$ & $6 \mathrm{~cm}$ & $8 \mathrm{~cm}$ & $3 \mathrm{~cm}$ \\
Erzurum & $13 \mathrm{~cm}$ & $16 \mathrm{~cm}$ & $10 \mathrm{~cm}$ & $13 \mathrm{~cm}$ & $5 \mathrm{~cm}$ \\
\hline
\end{tabular}



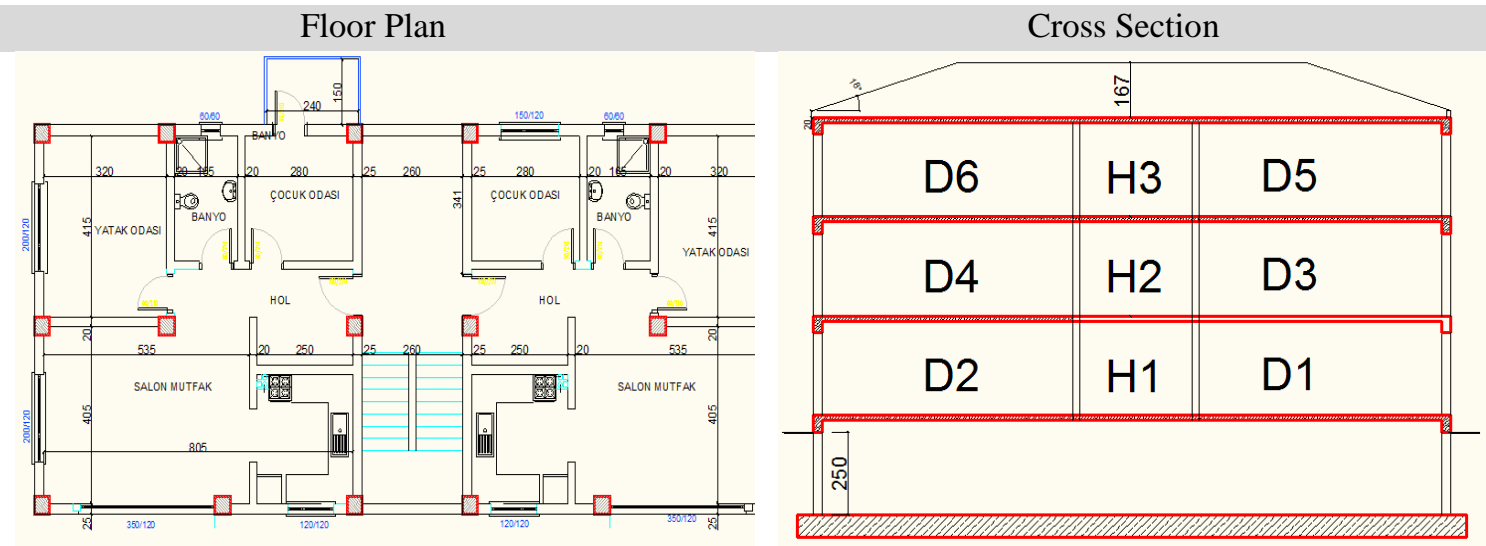

Fig. 1. The normal floor plan and cross section of the sample building

Table 3. General information regarding the sample building

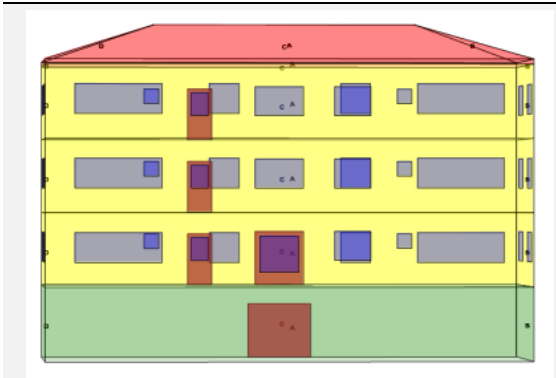

\begin{tabular}{ll}
\hline Building's Construction Type & Bricks or block building \\
External Wall & Plastered wall \\
Windows and Doors & Windows and doors with weather strip. \\
Beams' Frontal Height & $0,5 \mathrm{~m}$ \\
Number of Columns Touching the External & 14 \\
Elevated Flooring & None \\
Building's Form & Forms and dimensions are fixed \\
Floor Form & Rectangular \\
Roof Type & Jerkin Head \\
Number of Floors & 3 \\
Floor Height & $3 \mathrm{~m}$ \\
Roof Ridge Height & $1,67 \mathrm{~m}$ \\
Roof Side Height & $0,2 \mathrm{~m}$ \\
Closed Area of Use & $456,57 \mathrm{~m}^{2}$ \\
Basement Burying Level Depth & $2,5 \mathrm{~m}$ \\
\hline
\end{tabular}


Table 4.Zones of the Sample Building and Total Flooring Areas of Each Zone

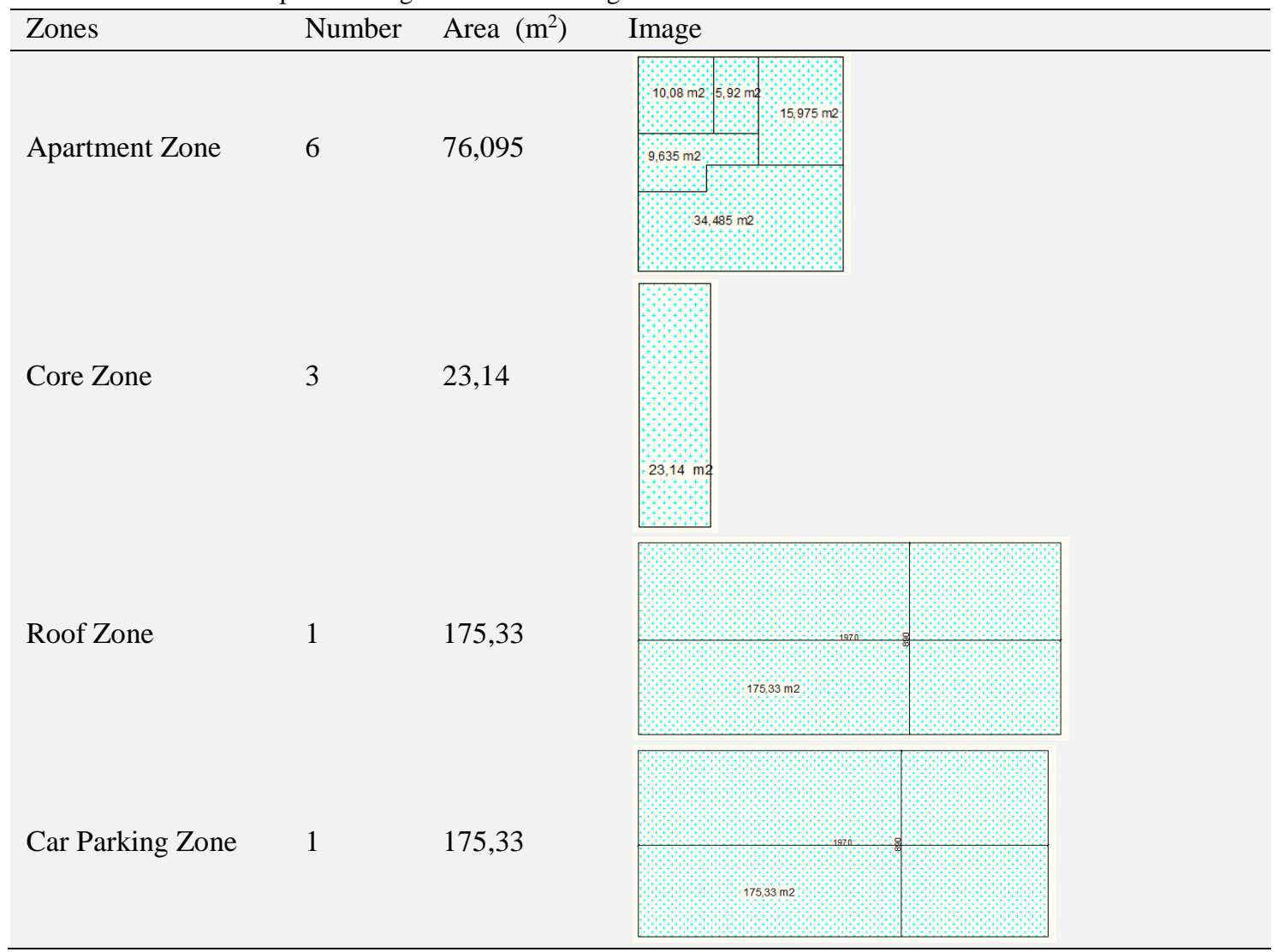

Table 5. Characteristics of the transparent element of exterior shell wall

\begin{tabular}{|c|c|c|c|}
\hline Location & $\begin{array}{c}\text { U Coefficient (W/m²K) } \\
\text { (TS } 825)\end{array}$ & Window Layers & Window Characteristics \\
\hline Antalya (1 $1^{\text {st }}$ Region) & & (Exterior) & Light transmittance: \\
\hline Trabzon ( $2^{\text {nd }}$ Region $)$ & & $4 \mathrm{~mm}$ glass & 0.80 \\
\hline Ankara (3 $3^{\text {rd }}$ Region) & 2.5 & $9 \mathrm{~mm}$ argon gas & Wood framed: \\
\hline Diyarbakır (4 $4^{\text {th }}$ Region $)$ & & $4 \mathrm{~mm}$ glass & $\mathrm{U}: 3.4 \mathrm{~W} / \mathrm{m}^{2} \mathrm{~K}$ \\
\hline Erzurum (5 $5^{\text {th }}$ Region $)$ & & (Interior) & \\
\hline
\end{tabular}

In the analyzed sample building, it has been assumed that:

- The used external shell transparent element is the same in all five climatic regions where the calculation is made (Table-5),

- The used fuel is natural gas and the heating system is central heating system,

- The ventilation system is natural ventilation and the cooling system is split air conditioner,

- The hot water system is natural gas heater,
- The illumination system is direct illumination, and all of the illumination devices are compact fluorescent lights.

In Scenario I, all characteristics of the sample building and the used construction components are accepted as the same, in the calculations made in the pilot cities chosen from five climatic regions, the calculation of the heating and cooling energy loads of the sample building is made by using XPS as thermal insulation material having $5 \mathrm{~cm}$ thickness value in the external shell of the building. 
While the sample building is formed, in every pilot city, the same opaque component materials are used in the same thicknesses (Table 6).
In Scenario II, all characteristics of the sample building and the used construction components are accepted as the same, in the calculations made in

Table 6. Opaque components used in the sample building, its materials and characteristics

\begin{tabular}{|c|c|c|c|c|}
\hline Opaque Components & Component Materials & $\begin{array}{l}\text { Heat } \\
\text { Transmission } \\
\text { Coefficient }(\chi) \\
\text { W/ } \mathrm{m}^{2} \mathrm{~K}\end{array}$ & $\begin{array}{l}\text { Thickness } \\
\text { (d) } \mathrm{m}\end{array}$ & $\begin{array}{l}\text { U Value } \\
\mathrm{W} / \mathrm{m}^{2} \mathrm{~K}\end{array}$ \\
\hline \multirow{4}{*}{ External Wall } & Gypsum Mortar & 0,7 & 0,02 & \multirow{4}{*}{0,41} \\
\hline & Horizontal Coring Brick & 0,33 & 0,19 & \\
\hline & XPS & 0,03 & 0,05 & \\
\hline & Cement Mortar & 1,6 & 0,03 & \\
\hline \multirow{3}{*}{$\begin{array}{l}\text { External Wall - } \\
\text { (Adjacent to the non- } \\
\text { heated interior } \\
\text { environment) }\end{array}$} & Gypsum Mortar & 0,7 & 0,02 & \multirow[b]{3}{*}{1,26} \\
\hline & Horizontal Coring Brick & 0,33 & 0,19 & \\
\hline & Cement Mortar with Lime & 1 & 0,02 & \\
\hline \multirow{5}{*}{ Beam } & Cement Mortar with Lime & 1 & 0,02 & \multirow{5}{*}{0,49} \\
\hline & Reinforced Concrete & 2,5 & 0,3 & \\
\hline & Cement Mortar & 1,6 & 0,03 & \\
\hline & XPS & 0,03 & 0,05 & \\
\hline & Inorganic Plaster Mortar & 0,35 & 0,01 & \\
\hline \multirow{4}{*}{ Curtain Wall } & Cement Mortar & 1,6 & 0,02 & \multirow{4}{*}{0,28} \\
\hline & Reinforced Concrete & 2,5 & 0,25 & \\
\hline & XPS & 0,03 & 0,10 & \\
\hline & $\begin{array}{l}\text { Polymer Bitumen Waterproof } \\
\text { Sheeting }\end{array}$ & 0,19 & 0,003 & \\
\hline \multirow{6}{*}{$\begin{array}{l}\text { Intermediate Floor } \\
\text { Flooring }\end{array}$} & Timber Cover & 0,13 & 0,005 & \multirow{6}{*}{0,51} \\
\hline & Screed with Cement Mortar & 1,4 & 0,03 & \\
\hline & Polyethylene Foil & 0,19 & 0,0005 & \\
\hline & XPS & 0,03 & 0,05 & \\
\hline & Reinforced Concrete & 2,5 & 0,12 & \\
\hline & Gypsum Mortar with Lime & 0,7 & 0,02 & \\
\hline \multirow{5}{*}{$\begin{array}{l}\text { Flooring - } \\
\text { Adjacent to the Non- } \\
\text { heated Interior } \\
\text { Environment }\end{array}$} & Timber Cover & 0,13 & 0,01 & \multirow{5}{*}{0,49} \\
\hline & Screed with Cement Mortar & 1,4 & 0,05 & \\
\hline & XPS & 0,03 & 0,05 & \\
\hline & Reinforced Concrete & 2,5 & 0,12 & \\
\hline & Cement Mortar with Lime & 1 & 0,03 & \\
\hline \multirow{8}{*}{ Ground Floor } & Timber Cover & 0,13 & 0,01 & \multirow{8}{*}{0,3} \\
\hline & Screed with Cement Mortar & 1,4 & 0,05 & \\
\hline & XPS & 0,03 & 0,05 & \\
\hline & Concrete screed & 2,5 & 0,5 & \\
\hline & Waterproofing- MasticAsphalt & 0,7 & 0,01 & \\
\hline & Plain Concrete & 1,65 & 0,15 & \\
\hline & Pumice Gravel & 0,19 & 0,2 & \\
\hline & Waterproofing -MasticAsphalt & 0,7 & 0,01 & \\
\hline \multirow{5}{*}{ Wooden Roof } & Plasterboards & 0,25 & 0,0125 & \multirow{5}{*}{0,19} \\
\hline & Oxidized & 110 & 0,0005 & \\
\hline & XPS & 0,03 & 0,15 & \\
\hline & Plywood & 0,13 & 0,016 & \\
\hline & Bituminous Water Insulation & 0,19 & 0,002 & \\
\hline
\end{tabular}


the pilot cities chosen from five climatic regions, the calculation of the heating and cooling energy loads of the sample building is made by using XPS as thermal insulation material having optimum thickness value determined for that region in the external shell of the building.

According to Scenario II, in other cities except Antalya province, a change took place in the heat insulation thickness value of only the external wall and beam components out of the opaque components (Table 7). All components except the external wall and beam components are accepted as the same as those of Scenario I indicated in Table 6.

Table 7. $U$ values of external wall and beam components that change according to the optimum insulation thickness used in the pilot cities

\begin{tabular}{|c|c|c|c|c|c|}
\hline Pilot Cities & $\begin{array}{l}\text { Opaque } \\
\text { Components }\end{array}$ & Component Materials & $\begin{array}{l}\chi \\
\mathrm{W} / \mathrm{m}^{2} \mathrm{~K}\end{array}$ & $\begin{array}{l}\text { Thickness } \\
\text { (d) } \mathrm{m}\end{array}$ & $\begin{array}{l}\text { U Value } \\
\mathrm{W} / \mathrm{m}^{2} \mathrm{~K}\end{array}$ \\
\hline \multirow{9}{*}{ Trabzon } & \multirow{4}{*}{ External Wall } & Gypsum Mortar & 0,7 & 0,02 & \multirow{4}{*}{0,32} \\
\hline & & Horizontal Coring Brick & 0,33 & 0,19 & \\
\hline & & XPS & 0,03 & 0,07 & \\
\hline & & Cement Mortar & 1,6 & 0,03 & \\
\hline & \multirow{5}{*}{ Beam } & Cement Mortar With Lime & 1 & 0,02 & \multirow{5}{*}{0,37} \\
\hline & & Reinforced Concrete & 2,5 & 0,3 & \\
\hline & & Cement Mortar & 1,6 & 0,03 & \\
\hline & & XPS & 0,03 & 0,07 & \\
\hline & & Inorganic Plaster Mortar & 0,35 & 0,01 & \\
\hline \multirow{9}{*}{ Ankara } & \multirow{4}{*}{ External Wall } & Gypsum Mortar & 0,7 & 0,02 & \multirow{4}{*}{0,26} \\
\hline & & Horizontal Coring Brick & 0,33 & 0,19 & \\
\hline & & XPS & 0,03 & 0,09 & \\
\hline & & Cement Mortar & 1,6 & 0,03 & \\
\hline & \multirow{5}{*}{ Beam } & Cement MortarWith Lime & 1 & 0,02 & \multirow{5}{*}{0,30} \\
\hline & & Reinforced Concrete & 2,5 & 0,3 & \\
\hline & & Cement Mortar & 1,6 & 0,03 & \\
\hline & & XPS & 0,03 & 0,09 & \\
\hline & & Inorganic Plaster Mortar & 0,35 & 0,01 & \\
\hline \multirow{9}{*}{ Diyarbakır } & \multirow{4}{*}{ External Wall } & Gypsum Mortar & 0,7 & 0,02 & \multirow{4}{*}{0,29} \\
\hline & & Horizontal Coring Brick & 0,33 & 0,19 & \\
\hline & & XPS & 0,03 & 0,08 & \\
\hline & & Cement Mortar & 1,6 & 0,03 & \\
\hline & \multirow{5}{*}{ Beam } & Cement MortarWith Lime & 1 & 0,02 & \multirow{5}{*}{0,33} \\
\hline & & Reinforced Concrete & 2,5 & 0,3 & \\
\hline & & Cement Mortar & 1,6 & 0,03 & \\
\hline & & XPS & 0,03 & 0,08 & \\
\hline & & Inorganic Plaster Mortar & 0,35 & 0,01 & \\
\hline \multirow{9}{*}{ Erzurum } & \multirow{4}{*}{ External Wall } & Gypsum Mortar & 0,7 & 0,02 & \multirow{4}{*}{0,20} \\
\hline & & Horizontal Coring Brick & 0,33 & 0,19 & \\
\hline & & XPS & 0,03 & 0,13 & \\
\hline & & Cement Mortar & 1,6 & 0,03 & \\
\hline & \multirow{5}{*}{ Beam } & Cement MortarWith Lime & 1 & 0,02 & \multirow{5}{*}{0,21} \\
\hline & & Reinforced Concrete & 2,5 & 0,3 & \\
\hline & & Cement Mortar & 1,6 & 0,03 & \\
\hline & & XPS & 0,03 & 0,13 & \\
\hline & & Inorganic Plaster Mortar & 0,35 & 0,01 & \\
\hline
\end{tabular}




\section{Findings and discussion}

According to Scenario I, the sample building is found to be in "C" energy class in all five climatic regions according to the final consumption amount obtained through average of heating, hot water, cooling, ventilation and illumination energy classes obtained through $5 \mathrm{~cm}$ XPS thermal insulation material in the Bep-Tr1 software Table 8.

The results in Scenario-I have indicated the significance of heating load in some regions, and of cooling load in some other regions. The amount of heating load comes to the fore according to the amount of cooling load in the mild - humid Trabzon province (2nd Region) alongside with mild - dry Ankara province (3rd Region). And in the Erzurum province (5th Region) the amount of the heating load appears to be in the highest levels. In the hot humid Antalya province (1st Region) cooling load comes to the fore and in hot - dry Diyarbakır (4th Region) both heating and cooling loads become important equally.

According to Scenario II, when the calculation of the energy loads are made by using the optimum thermal insulation thickness values of the sample buildings in the selected pilot provinces in Bep-Tr1, no change has taken place in the hot water, ventilation and illumination energy loads as all other conditions are accepted as the same as those that are in Scenario I, the change is observed in only heating and cooling energy loads. According to the final consumption amount obtained in the consequence of Scenario II and determined by the average heating, hot water, cooling, ventilation and illumination energy loads, as the $5 \mathrm{~cm}$ thickness value implemented in Scenario I in the Antalya province in the 1st Region is also the optimum thermal insulation thickness value at the same time, the obtained values in the consequence of the calculation and energy class for this region has not changed, it has remained the same as " $\mathrm{C}$ " energy class also in Scenario II.

As it is seen in Table 9, in the consequence of the calculations by taking the optimum heat insulation thickness value as $7 \mathrm{~cm}$ in the Trabzon province in the 2nd Region, the energy class of the sample building has stepped from the "C" energy class to the " $\mathrm{B}$ " energy class. In the same manner, in the consequence of the calculations by taking the optimum thermal insulation thickness value as 13 $\mathrm{cm}$ in the Erzurum province in the 5th Region, the energy class of the sample building has stepped from the " $C$ " energy class to the " $\mathrm{B}$ " energy class.

Table 8. Heating and cooling loads and energy classes obtained in Scenario I

\begin{tabular}{|c|c|c|c|c|c|}
\hline $\begin{array}{l}\text { Region - } \\
\text { Pilot City }\end{array}$ & $\begin{array}{l}\text { Energy } \\
\text { Type }\end{array}$ & $\begin{array}{l}\text { Energy } \\
\text { Amount } \\
\mathrm{kWh} / \mathrm{m}^{2}\end{array}$ & $\begin{array}{l}\text { Energy } \\
\text { Classification }\end{array}$ & $\begin{array}{l}\text { Final } \\
\text { Consumption } \\
\text { kWh/year }\end{array}$ & $\begin{array}{l}\text { Total } \\
\text { Energy } \\
\text { Classification }\end{array}$ \\
\hline \multirow{2}{*}{$\begin{array}{l}1^{\text {st }} \text { Region - } \\
\text { Antalya } \\
\text { (Hot-Humid) }\end{array}$} & Heating Energy Load & 32.913 & B & \multirow{2}{*}{187.267} & \multirow{2}{*}{$\mathrm{C}$} \\
\hline & Cooling Energy Load & 128.140 & $\mathrm{D}$ & & \\
\hline \multirow{2}{*}{$\begin{array}{l}2^{\text {nd }} \text { Region - } \\
\text { Trabzon } \\
\text { (Mild-Humid) }\end{array}$} & Heating Energy Load & 125.205 & B & \multirow[b]{2}{*}{199.752} & \multirow[b]{2}{*}{$\mathrm{C}$} \\
\hline & Cooling Energy Load & 48.333 & D & & \\
\hline \multirow{2}{*}{$\begin{array}{l}3^{\text {rd }} \text { Region - } \\
\text { Ankara } \\
\text { (Mild-Dry) }\end{array}$} & Heating Energy Load & 199.763 & $\mathrm{C}$ & \multirow{2}{*}{309.207} & \multirow{2}{*}{$\mathrm{C}$} \\
\hline & Cooling Energy Load & 83.229 & $\mathrm{D}$ & & \\
\hline \multirow{2}{*}{$\begin{array}{l}4^{\text {th }} \text { Region - } \\
\text { Diyarbakır } \\
\text { (Hot-Dry) }\end{array}$} & Heating Energy Load & 124.006 & B & \multirow{2}{*}{286.939} & \multirow{2}{*}{$\mathrm{C}$} \\
\hline & Cooling Energy Load & 136.718 & $\mathrm{D}$ & & \\
\hline \multirow{2}{*}{$\begin{array}{l}5^{\text {th }} \text { Region - } \\
\text { Erzurum } \\
\text { (Cold) }\end{array}$} & Heating Energy Load & 379.710 & $\mathrm{C}$ & \multirow{2}{*}{446.639} & \multirow{2}{*}{$\mathrm{C}$} \\
\hline & Cooling Energy Load & 40.714 & $\mathrm{D}$ & & \\
\hline
\end{tabular}


Table 9. Heating and cooling loads and energy classes obtained in Scenario II

\begin{tabular}{|c|c|c|c|c|c|c|}
\hline $\begin{array}{l}\text { Region - } \\
\text { Pilot City }\end{array}$ & $\begin{array}{l}\text { Energy } \\
\text { Type }\end{array}$ & & $\begin{array}{l}\text { Energy } \\
\text { Amount } \\
\mathrm{kWh} / \mathrm{m}^{2}\end{array}$ & $\begin{array}{l}\text { Energy } \\
\text { Classification }\end{array}$ & $\begin{array}{l}\text { Final } \\
\text { Consumption } \\
\text { kWh/year }\end{array}$ & $\begin{array}{l}\text { Total } \\
\text { Energy } \\
\text { Classification }\end{array}$ \\
\hline \multirow{2}{*}{$\begin{array}{l}1^{\text {st }} \text { Region - } \\
\text { Antalya } \\
\text { (Hot-Humid) }\end{array}$} & $\begin{array}{l}\text { Heating } \\
\text { Load }\end{array}$ & Energy & 32.913 & B & \multirow[t]{2}{*}{187.267} & \multirow[t]{2}{*}{$\mathrm{C}$} \\
\hline & $\begin{array}{l}\text { Cooling } \\
\text { Load }\end{array}$ & Energy & 128.140 & $\mathrm{D}$ & & \\
\hline \multirow{2}{*}{$\begin{array}{l}2^{\text {nd }} \text { Region - } \\
\text { Trabzon } \\
\text { (Mild-Humid) }\end{array}$} & $\begin{array}{l}\text { Heating } \\
\text { Load }\end{array}$ & Energy & 117.322 & B & \multirow[t]{2}{*}{193.243} & \multirow[t]{2}{*}{ B } \\
\hline & $\begin{array}{l}\text { Cooling } \\
\text { Load }\end{array}$ & Energy & 49.706 & $\mathrm{E}$ & & \\
\hline \multirow{2}{*}{$\begin{array}{l}3^{\text {rd }} \text { Region - } \\
\text { Ankara } \\
\text { (Mild-Dry) }\end{array}$} & $\begin{array}{l}\text { Heating } \\
\text { Load }\end{array}$ & Energy & 181.304 & B & \multirow[t]{2}{*}{293.535} & \multirow[t]{2}{*}{$\mathrm{C}$} \\
\hline & $\begin{array}{l}\text { Cooling } \\
\text { Load }\end{array}$ & Energy & 86.017 & $\mathrm{D}$ & & \\
\hline \multirow{2}{*}{$\begin{array}{l}4^{\text {th }} \quad \text { Region } \\
\text { Diyarbakır } \\
\text { (Hot-Dry) }\end{array}$} & $\begin{array}{l}\text { Heating } \\
\text { Load }\end{array}$ & Energy & 112.872 & B & \multirow[t]{2}{*}{278.022} & \multirow[t]{2}{*}{$\mathrm{C}$} \\
\hline & $\begin{array}{l}\text { Cooling } \\
\text { Load }\end{array}$ & Energy & 138.936 & $\mathrm{D}$ & & \\
\hline \multirow{2}{*}{$\begin{array}{l}5^{\text {th }} \text { Region - } \\
\text { Erzurum } \\
(\text { Cold })\end{array}$} & $\begin{array}{l}\text { Heating } \\
\text { Load }\end{array}$ & Energy & 329.163 & B & \multirow[t]{2}{*}{399.950} & \multirow[t]{2}{*}{ B } \\
\hline & $\begin{array}{l}\text { Cooling } \\
\text { Load }\end{array}$ & Energy & 44.573 & $\mathrm{E}$ & & \\
\hline
\end{tabular}

And in the consequence of the calculations by taking the optimum thermal insulation thickness value as $9 \mathrm{~cm}$ in the Ankara province in the $3 \mathrm{rd}$ Region, and by taking the optimum thermal insulation thickness value as $8 \mathrm{~cm}$ in the Diyarbakır province, the energy class of the sample building has not changed and it has remained the same as "C" energy class despite the fact that there was a change in the heating and cooling energy loads.

In the consequence of calculation obtained from the Bep-Tr1 software which calculates by the simple hourly dynamic method, an average of $10 \%$ decrease in the heating energy load, and an average of $4 \%$ increase in the cooling energy load of the sample buildings are observed in all regions by increasing the insulation thickness value to the optimum thickness value. It is believed that the inability of the building to benefit from the night cooling through the increasing of the insulation thickness has caused the increase in the cooling loads.
Despite that the average $10 \%$ decrease obtained in the building's heating load through the optimum thermal insulation thickness is an important result; it has not become very influential in changing the total energy class of the building.

- The impact of the outcomes obtained through the calculations by using the heat insulation materials in the optimum thickness in the BepTr1 software has come out low. It is of significance to correctly make the determination of the impact factor of the building component materials in the software.

- The fact that the energy classes of the sample buildings in the $3^{\text {rd }}$ and $4^{\text {th }}$ regions have not changed in the consequence of calculations made by increasing the heat insulation material's thickness almost by 1.5 and 2 times has indicated that the energy class intervals in the Bep-Tr1 software have been kept wide.

- Despite the fact that the thermal insulation materials' optimum thickness values provide significant results in lowering down the 
buildings' energy loads in the calculations made through the Bep-Tr1 software which are thought to be important in determining the energy performance of the buildings, their failure to provide the expected impact in changing the energy class of the buildings have importance as it would decrease the buildings' energy performance by negatively influencing the use of the thermal insulation optimum thickness values.

\section{Conclusions}

With this conducted study, the Bep-Tr1 software, which has been developed for building energy certification in Turkey, has been examined; the impact of the optimum thermal insulation thickness value on the energy class of the buildings which is thought to be important in determining the buildings' energy performance and obtaining energy efficiency and the following results are obtained:

- In the calculations made through accepting the thermal insulation materials' thickness value as $5 \mathrm{~cm}$ in all five climatic regions, the fact that the sample buildings' energy class turned out to be "C energy class" in all climatic regions and the use of average standard heat insulation thickness values in Turkey without regarding the climatic regions have shown us that it has provided us the necessary energy class. This situation would negatively influence the energy efficiency to be obtained in the buildings.

- By the study made in Bep-Tr1 software, the impact factor of the optimum thermal insulation thickness value in the program has turned out to be low. Through the use of optimum thermal insulation thickness value, an average of $10 \%$ heating load efficiency has been provided in all regions. However, the failure of this efficiency to be reflected in the buildings' energy classes in all climatic regions would negatively impact the applications of the optimum thermal insulation thickness.

- The failure of the energy class of the sample buildings to change in the $3 \mathrm{rd}$ and 4 th regions in the consequence of making calculations by using the optimum thermal insulation thickness value has shown that the energy class intervals in the Bep-Tr1 software have been kept widely.

In the following studies within the scope of this study, in the Bep-Tr2 program as it is revised by the Ministry, the analysis of the impact of the optimum thermal insulation thickness on the building's energy loads and energy class would be one of the matters that need to be contemplated. It is important that the building energy certification has the characteristics of a document which aims to create buildings with high energy efficiency most appropriate for the standards and conditions determined in the directives rather than being a document of formality indicating that the buildings have been qualified for the necessary energy class. Nowadays, the energy class of the buildings has started to be used as a matter of prestige all around the world alongside with Europe. In this case, the ability of our National Building Energy Performance Calculation software (Bep-Tr1) to display the necessary care in determining the energy classes of the buildings would allow the determination of real class differences between buildings in Turkey. This situation would provide great contributions to taking necessary steps in terms of energy efficiency in our country which is dependent on outside sources in energy.

\section{References}

[1] Doğu Marmara ABİGEM. Yap1 ve Yap1 Malzemeleri Sektör Raporu, 2012.

[2] Çomaklı K, Yüksel B (2003) Optimum insulation thickness of external walls for energy saving. Applied Thermal Engineering 3: 473-479.

[3] Bolattürk A (2006) Determination of optimum insulation thickness for building walls with respect to various fuels and climate zone in Turkey. Applied Thermal Engineering 26: 1301-1309.

[4] Kaynaklı Ö, Yamankaradeniz R. Heating process and optimum insulation thicjness calculation. VIII National Plumbing Engineering Congress, 2007 Izmir, Turkey (in Turkish).

[5] Özel M, Piht1lı K (2008) Determination of optimum insulation thickness by using heating and cooling degree-day values. Journal of Engineering and Natural Sciences 26(3): 191-197. 
[6] Gürel AE, Cingiz Z (2011) Economic analysis of optimum thermal insulation thickness detection for different exterior wall structures. SAU Journal of Science 15(1): 75-81.

[7] Kürekçi A, Bardakçı AT, Çubuk H, Emanet Ö (2012) Determination of Optimum Insulation Thickness for all provinces in Turkey. Tesisat Mühendisliği Dergisi 131: 5-21.

[8] Bep-Tr, Building Energy Performance Calculation Method-I Training Report. Chamber of Architects, 2010.

[9] Izocam, Açıklamalı ve Örneklerle TS825 Binalarda Is1 Yalıtım Kuralları Standardı, 2013.

[10] URL-1, http://www.karplus.com.tr/TR/illeregoreisiyalitim kalinliklari, Access: January, 2018. 